\title{
Climate Change and the Future of Winter Tourism in Slovenia
}

\author{
Matej Ogrin, Darko Ogrin, Nastja Rodman, Matic Močnik, \\ Rok Vengar, Andraž Smolej, Gregor Bunčič
}

\begin{abstract}
Climate changes are affecting many activities in modern society all over the world. In Europe, the Alps are among the most affected regions, where rises in temperature and snow lines (Kohler, Maselli, 2009) and changed distribution of precipitation have already brought changes in society. Alpine tourism has undergone changes due to warmer and greener winters, so ski areas face lack of profit, some have even stopped operating, while others have changed their strategy and shifted their offer to all-year activities instead focusing only on winter (Vrtačnik Garbas, 2008). In Slovenia, most of the ski slopes lie at very low elevations compared with other Alpine countries, so most of these centres are even more endangered by global warming. The article focuses on climate trends in the Slovenian mountains, especially in the ski season months, from December to March.
\end{abstract}

Key words: climate change, winter tourism, the Alps, Slovenia

\section{Klimatske promjene i budućnost zimskog turizma u Sloveniji}

Klimatske promjene utječu na niz aktivnosti modernog društva diljem svijeta. U Europi, Alpe su jedno od područja najviše zahvaćenih klimatskim promjenama, gdje su povišene temperature i snježne linije (Kohler, Maselli, 2009) i izmijenjena raspodjela padalina već dovele do društvenih promjena. Alpski turizam doživio je promjene zbog toplijih, zelenih zima, tako da su skijaška područja suočena s manjim profitima. Neka su prestala s radom, dok su druga promijenila svoju strategiju i prebacila se na pružanje usluga tijekom cijele godine, umjesto orijentacije isključivo na zimu (Vrtačnik Grabas, 2008). Većina skijaških padina u Sloveniji nalazi se na nižim uzvisinama u usporedbi s ostalim alpskim državama, pa je većina tih centara još više ugrožena globalnim zatopljenjem. Ovaj se članak fokusira na klimatske trendove u slovenskim planinama, posebno tijekom skijaške sezone, od prosinca do ožujka.

Ključne riječi: klimatske promjene, zimski turizam, Alpe, Slovenija 


\section{INTRODUCTION}

The Slovenian Alpine Region is situated on the outermost south-eastern part of the Alps. Because of this, the mountains in Slovenia do not reach great heights and the influence of other macroregional units can be noticed both on the surface as well as in the climate. This also has an effect on other landscape characteristics. The influence of the Mediterranean is mainly visible in the larger amount of precipitation, which is particularly distinctive for the western, southern and south-western parts of the Slovenian Alpine world (Ogrin D., Plut, 2009, p. 81). The influence of the sea is felt in the higher temperatures in the mountainous parts facing southward in comparison to those to the north or closer to the interior of Slovenia. This influence can be felt above all in the winter. The influence of the Pannonian or continental climate can be observed in the eastern part, especially in the division of the precipitation and the stronger influence of the air masses from the east up to the watershed between the Sava and Soča Rivers (Perko, Orožen Adamič, 1998, p.42, Ogrin $D, .2008$ ). In recent decades, the climate of this area has gone through changes, which can be seen in rising temperatures (Ogrin D., 2003, Dolinar et al., 2010, Dolinar, Vertačnik, 2010). Another obvious change is also the frequency of extreme weather, such as heavy rain, strong winds, storms and the like. To what extent are these climate changes already reflected in the environmental parameters that are important for winter tourism? After the green winters in the late 1980s and the increasingly warm winters in the 1990s, what interests us today is to what extent the temperatures have already risen with regard to the past periods (for example the climate from 1961-1990), what changes this will bring and, of course, to extent to which the temperatures will rise in the future. Climate models are the best tool we have for prediction of future climate. However, information from numerous weather stations that have been monitoring the weather for decades can be used for the analysis of past periods. The purpose of this article is to show the environmental trends in temperature and snow cover in the Slovenian Alps over the last 30 years in the context of climate change, with the emphasis on winter tourism.

\section{METHODOLOGY}

In our research on climate changes and the future of winter tourism (with the emphasis on ski tourism) in Slovenia, we have analysed the temperature and snow conditions on the basis of the collected and analysed quantitative data. An interpretative method was used to explain the results of the analysis. The data was collected from the daily measurements of the chosen meteorological stations for the so-called skiing months during the years from 1979 to 2008, taking into account that the main skiing season in Slovenia usually starts in December and lasts until the end of March (ski resorts up to elevations c. $1800 \mathrm{~m}$ a.s.1.). Quantitative data for the analysis were obtained from the archive database of the meteorological stations of the Environmental Agency of the Republic of Slovenia (ARSO).

As the higher parts of some of the biggest ski resorts lie at elevations above $1800 \mathrm{~m}$ a.s.l., we also checked the temperature conditions in the high Alpine areas for comparison. The following meteorological stations were included in the analysis: Rateče ( $864 \mathrm{~m}$. a.s.1.), Planina pod Golico (970 m. a.s.1.), Lisca (943 m. a.s.1.) and Kredarica (2514 m. a.s.1.). In the Slovenian Alpine and Pre-Alpine areas, there are quite a few other stations, but their 


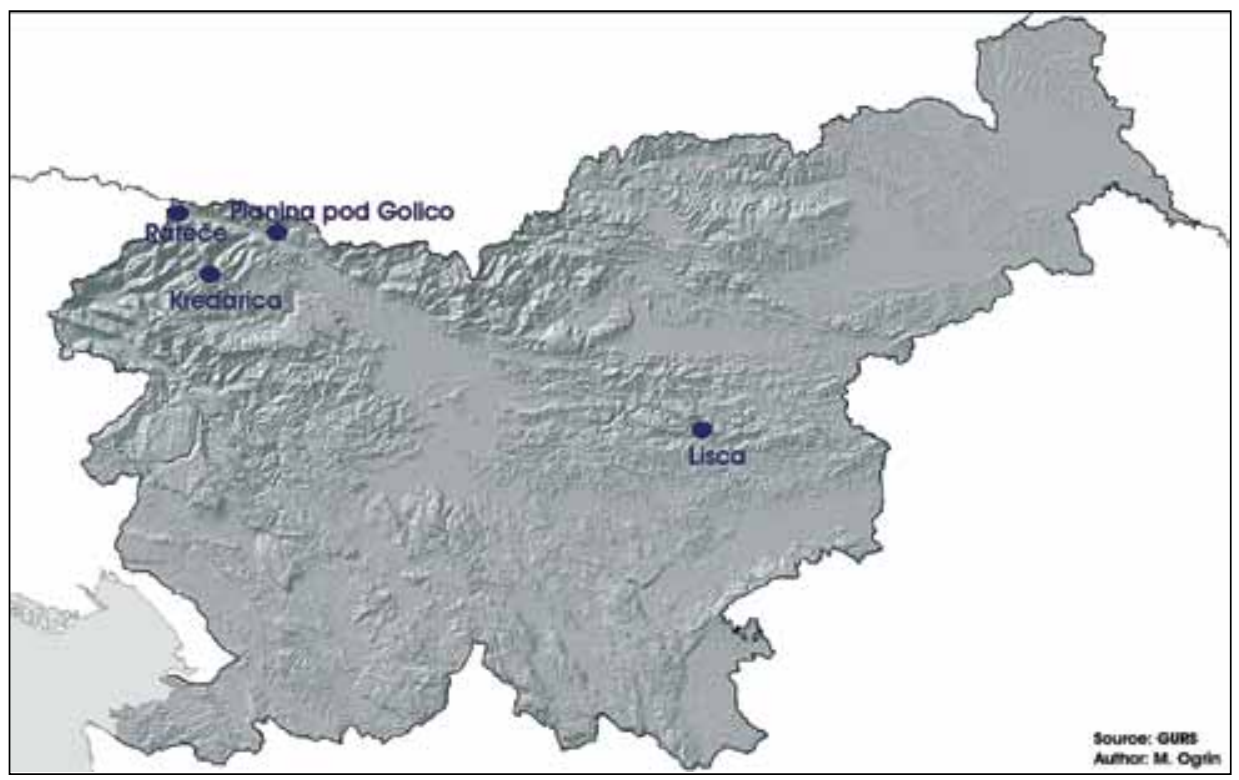

Fig. 1 Area of research

Sl. 1 Istraživano područje

reference periods are too short or incomplete. Among the chosen stations, Lisca has a similar problem, as its reference period is only 25 years long. Nevertheless it was included into the analysis, as it is the only station from the mountainous region of eastern Slovenia.

The surface of the ground needs to cool to or below $0{ }^{\circ} \mathrm{C}$ for the snow cover to form. One of the main indicators of the snow conditions is the number of days with snow cover. However, this alone still does not provide satisfactory skiing conditions, since the snow needs to be deep enough. Nevertheless, it is considered to be one of the main indicators. As the primary condition for skiing, we defined $30 \mathrm{~cm}$ as the minimum depth of snow cover. This is sufficient, especially if the ski slope is not on karst terrain and is covered with a layer of soil thick enough and grass-covered (Vrtačnik Garbas, 2008). If a 30-cm deep snow cover is enough for good skiing, a 50-cm deep snow cover provides much better skiing conditions, except on very rocky terrain. Furthermore, a thick snow cover ensures a long ski season. This indicator is not essential and has a supplementary effect, but it shows an interesting course of snow conditions. That is why several other indicators were used in the analysis of the temperature conditions, including average annual air temperature, and average air temperature in the analysed four-month period (December, January, February, March); we also calculated the linear trend.

The analysis of snow conditions included the following indicators: the number of days with snow cover in December, January, February, March; number of days with snow cover thicker than $30 \mathrm{~cm}$ (in the same period); and, number of days with snow cover thicker than $50 \mathrm{~cm}$ (in the same period). In this case, linear trends were also calculated. The period of analysis is 30 years long: from the winter of $1979 / 80$ to the winter of $2008 / 09$. As was the case with temperatures, linear trends for snow conditions were also calculated. 


\section{TEMPERATURE CONDITIONS IN THE PERIOD FROM 1979/80 TO 2008/09}

Besides snow cover, air temperature is one of the main conditions for good skiing and for the snow cover to form and last. Climate changes are a threat to winter tourism, especially in this area, because the rise in temperatures means faster thawing of the snow cover and more rain instead of snow. So the snow cover forms later, the periods without snow cover during winter are more frequent and the snow melts faster in spring. For the whole Alps at middle elevations, the duration of snow cover is expected to decrease by several weeks for each degree C of warming (Kohler, Maselli, 2009, p. 9). Apart from that, making artificial snow is more expensive or even impossible with higher temperatures.

In Europe, especially in the Alps, several in-depth studies have been carried out, which all show that snow conditions are deteriorating, especially on ski resorts at lower elevations. Abegg (1996) reports that at the end of the 20th century in Switzerland a sufficient snow cover was formed at the elevation of $1200 \mathrm{~m}$. If the temperature rises by $2{ }^{\circ} \mathrm{C}$, this limit will rise to 1500 m. a.s.l. Koch and Rudel (cited in: König, 1998) report that a temperature rise by $2{ }^{\circ} \mathrm{C}$ would cause the lower-lying ski resorts of Lower Austria, Upper Austria and Styria to stop operating; only the ski resort at higher elevations in Western Austria would still be in operation. The Global Outlook for Ice and Snow says that in the previous 40 years, the degree of snow cover reduction in the Northern Hemisphere was $1.3 \%$ per decade, the reduction being the greatest in the spring and summer. Snow cover forecasts show a $60-80 \%$ reduction of snow cover in water equivalent by the end of the 21 st century in most parts of moderate latitudes, with an expected increase in snow cover

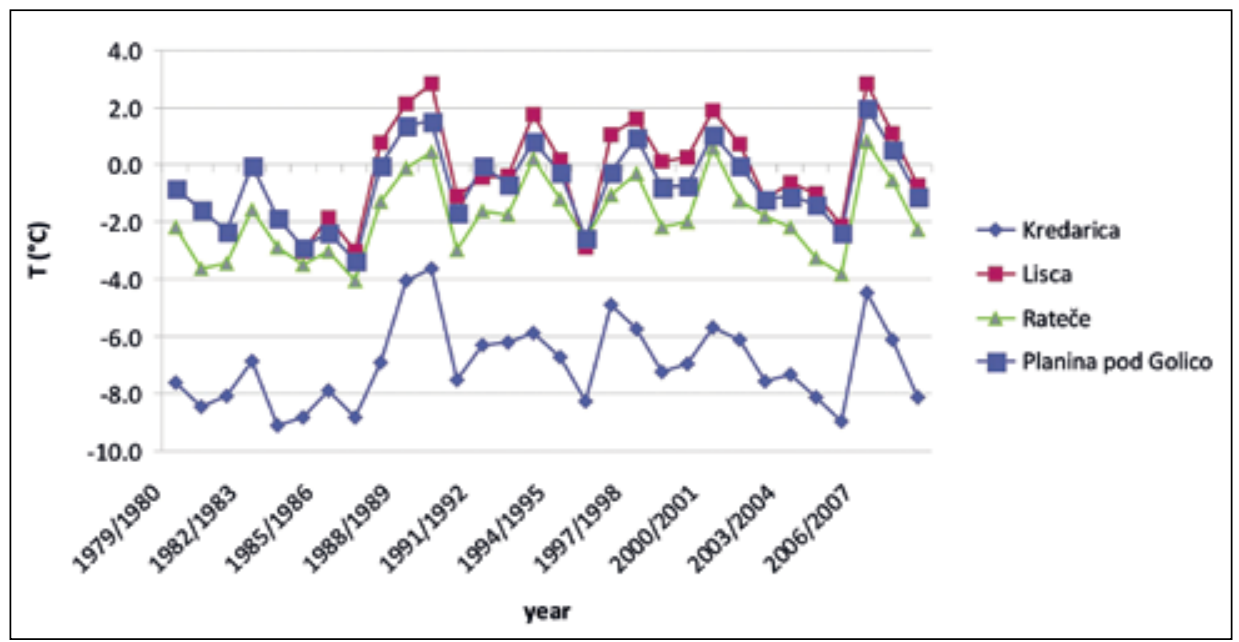

Fig. 2 Average air temperature $\left({ }^{\circ} \mathrm{C}\right)$ in the four-month periods (December, January, February, March) from 1979/80 to 2008/09 from Kredarica (2514 m), Lisca (937 m), Rateče (864 m) and Planina pod Golico $(970 \mathrm{~m})$

Sl. 2. Prosječne temperature zraka $\left({ }^{\circ} \mathrm{C}\right.$ ) tijekom četveromjesečnog razdoblja (prosinac, siječanj, veljača, ožujak) od 1979/80. do 2008/09. za Kredaricu (2514m), Liscu (937m), Rateču (864m) i Planinu pod Golico $(970 m)$.

* data for Lisca was taken over the 1985-2009 reference period

* podaci za Liscu su za razdoblje 1985 - 2009. 
only in the Canadian Arctic and Siberia (Barry et al., 2010). The study Mountains and Climate Change by Kohler and Maselli (2009) shows that since 1979 Europe has been warming faster than the global trend and the temperature rise in the mountains is higher (Boehm et al. cited in Kohler, Maselli, 2009)

This research is focused on temperature conditions at the chosen stations in the Slovenian Alpine world, mainly from the last 30 years, exceptionally also from shorter periods.

As expected, the lowest temperatures were recorded on the highest elevations. The average winter temperatures at Kredarica never rose above $-3.6^{\circ} \mathrm{C}$, while the average temperature from December to March was $-7.0{ }^{\circ} \mathrm{C}$. At the rest of the stations, which all lie at elevations around $900 \mathrm{~m}$, the temperatures measured in the same period were much higher. The average temperature at Rateče was $-1.8^{\circ} \mathrm{C}$, the highest $0.8^{\circ} \mathrm{C}$, at Planina pod Golico $-0.7^{\circ} \mathrm{C}$ and the highest $1.4^{\circ} \mathrm{C}$, while the average temperature at Lisca was exactly $0{ }^{\circ} \mathrm{C}$, and the highest temperature $2.8^{\circ} \mathrm{C}$. The fact that Rateče is the coldest among the three stations and, at the same time, the lowest-lying station, is connected with its position in a valley where temperature inversion is a frequent phenomenon. More informative are the linear trends of the average monthly temperatures from the stations mentioned, as shown in Fig. 3.

The trends of average winter temperatures are moving in a positive direction in the case of all the mentioned stations, which is alarming from the point of view of winter tourism at the Slovenian ski centres. The linear warming trend is the strongest at Rateče

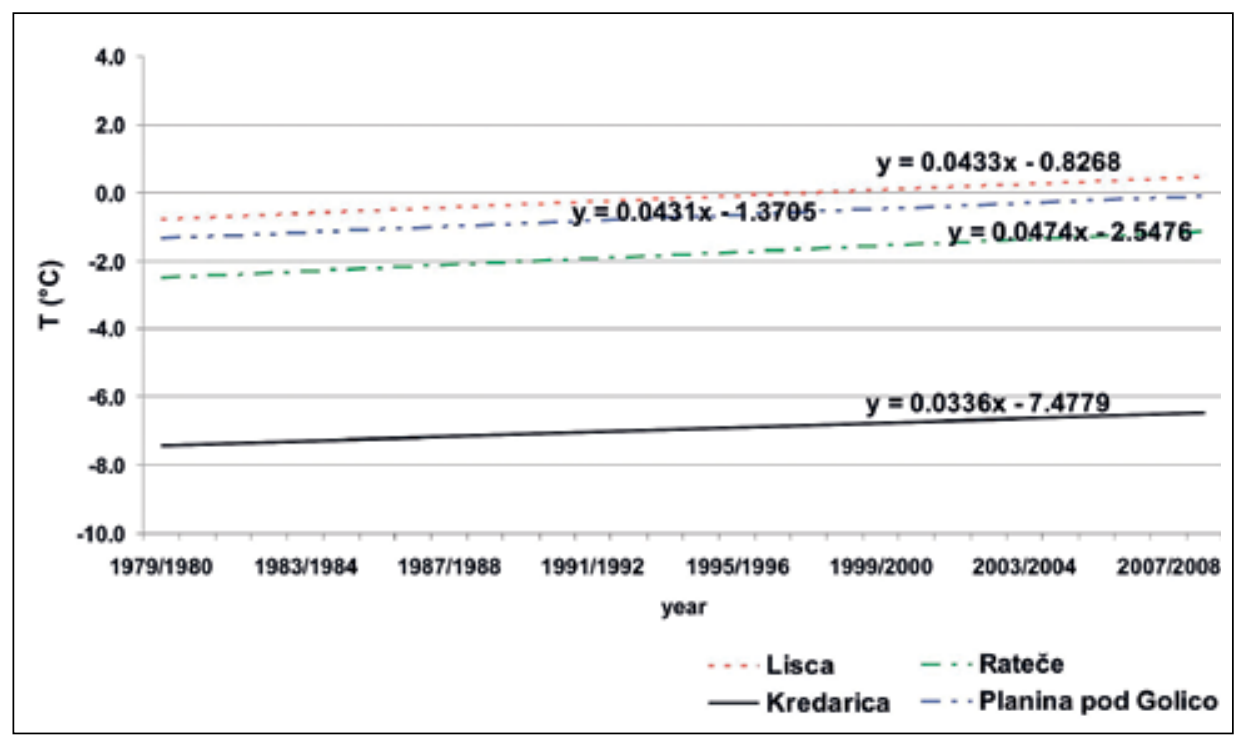

Fig. 3 Linear trends of average air temperature movement $\left({ }^{\circ} \mathrm{C}\right)$ from January to December from $1979 / 80$ to 2008/09 from Kredarica (2514 m), Lisca (937 m), Rateče (864 m) and Planina pod Golico (970 m)

Sl. 3. Linearni trendovi kretanja prosječne temperature zraka $\left({ }^{\circ} \mathrm{C}\right)$ od siječnja do prosinca od 1979/80. do 2008/09. za Kredaricu (2514m), Liscu (937m), Rateču (864m) i Planinu pod Golico (970m) .

* Data for Lisca was measured over the 1985-2009 reference period

* podaci za Liscu su za razdoblje 1985 - 2009 
and Planina pod Golico with $1.4^{\circ} \mathrm{C}$ per 30 years, while at Lisca the trend is weaker by only a tenth. The warming trend is weaker at Kredarica with $1{ }^{\circ} \mathrm{C}$, which shows the conditions in high Alpine areas, where only one Slovenian ski resorts lies (Kanin).

Tab. 1: Average air temperatures $\left({ }^{\circ} \mathrm{C}\right)$ in the four-month period (January, February, March, December) from $1979 / 80$ to $2008 / 09$

Tab. 1. Prosječne temperature zraka $\left({ }^{\circ} \mathrm{C}\right)$ tijekom četveromjesečnog razdoblja (prosinac, siječanj, veljača, ožujak) od 1979/80. do 2008/09.

\begin{tabular}{|c|c|c|c|c|}
\hline & $1980-1989$ & $1990-1999$ & $2000-2009$ & $1980-2009$ \\
\hline Kredarica $(2514 \mathrm{~m})$ & -7.7 & -6.2 & -7.0 & -7.0 \\
\hline Planina pod Golico $(970 \mathrm{~m})$ & -1.4 & -0.4 & -0.3 & -0.7 \\
\hline Lisca* $(937 \mathrm{~m})$ & & 0.3 & 0,1 & $0.0 *$ \\
\hline Rateče $(864 \mathrm{~m})$ & -2.6 & -1.3 & -1.6 & -1.8 \\
\hline
\end{tabular}

* Data for Lisca was calculated over the 1989/90-2008/2009 reference period

* podaci za Liscu su za razdoblje 1989/90. do 2008/09.

In the thirty-year period, the temperatures were the lowest in the 1980s; after that, they gradually started rising and from the $1990 \mathrm{~s}$ on they rose by about 0.7 to $1.1{ }^{\circ} \mathrm{C}$. The data from Kredarica stand out because of its higher elevation in comparison to the other stations.

The only station with positive air temperature over the four-month periods of the last two decades is Lisca. The average air temperature for the mentioned period was just below freezing point at Planina pod Golico as well, while the temperatures over the fourmonth periods at Rateče in the previous decade were even a bit lower than in the 1990s.

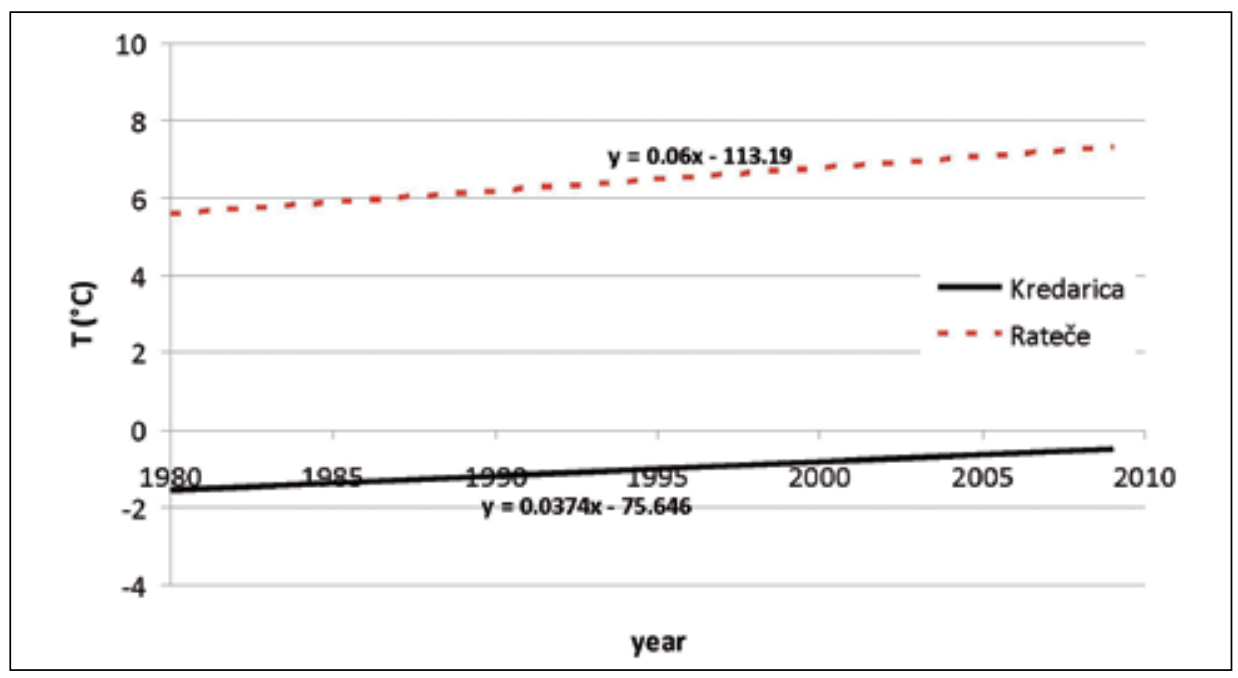

Fig. 4 Linear trends of average annual air temperature $\left({ }^{\circ} \mathrm{C}\right)$ from 1980 to 2009 from Kredarica $(2514 \mathrm{~m})$ and Rateče $(864 \mathrm{~m})$

Sl. 4. Linearni trendovi prosječne godišnje temperature zraka $\left({ }^{\circ} \mathrm{C}\right)$ od 1980. do 2009. za Kredaricu $(2514 \mathrm{~m})$ i Rateče $(864 \mathrm{~m})$. 
Fig. 4 shows a substantial increase at Kredarica and Rateče in the annual average temperatures during 1980 and 2009 as well. At the other two locations besides Kredarica and Rateče, a temperature rise can also be observed. The average air temperatures in the four-month periods and the annual average air temperatures have risen. The only exception is the month of December, when the average air temperatures dropped slightly.

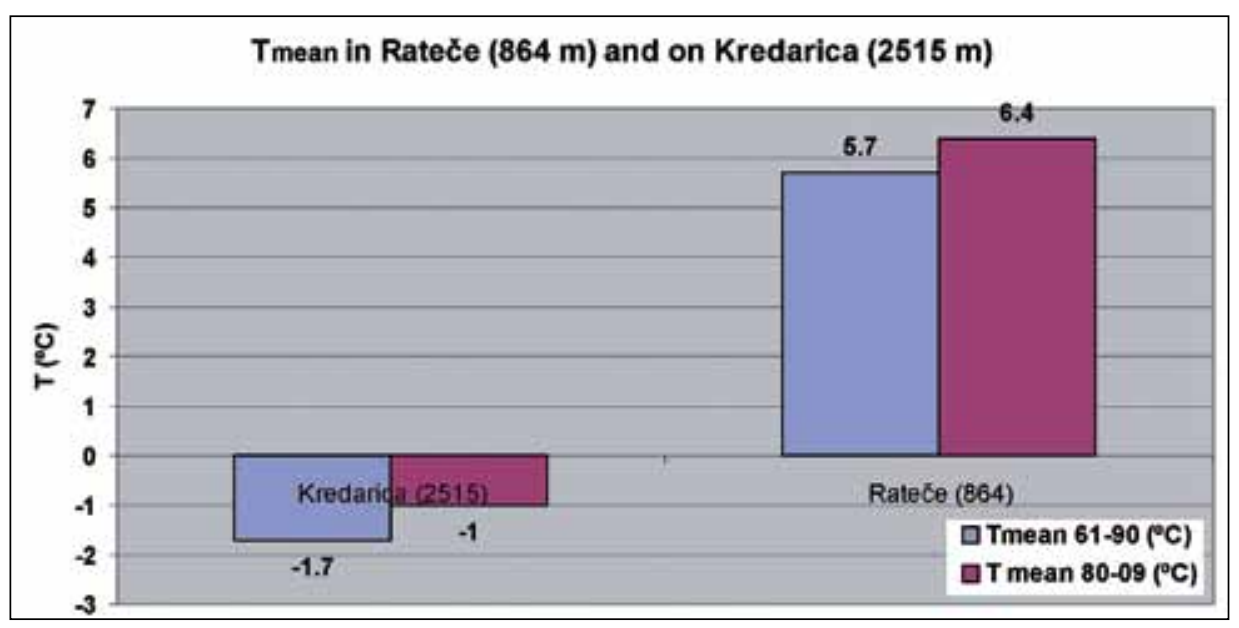

Fig. 5 Comparison of the average air temperature $\left({ }^{\circ} \mathrm{C}\right)$ from Kredarica $(2514 \mathrm{~m})$ and Rateče $(864 \mathrm{~m})$ in 1961 - 1990 and in $1980-2009$

Sl. 5. Usporedba prosječnih temperatura zraka za Kredaricu (2514 m) i Rateče (864 m) tijekom 1961-1990. i 1980-2009.

The rise in temperatures is obvious, in winter as well as during the year. An interesting fact is that the data measured in December at each station do not indicate a warming trend. The cause of this remains unknown. At the elevation of $1000 \mathrm{~m}$, the warming trend is higher than at the only station in the high Alpine areas of Slovenia. The trouble we came across when observing the data is the incomplete reference period or incomplete measurements, which have a negative effect on the quality of the analysis.

\section{SNOW CONDITIONS}

Snow cover is the essential condition for a ski resort to be in operation. Snow cover can be formed naturally by falling snow, or it can be made artificially by using snow canons, which produce artificial or compact snow. In this article, natural conditions, which enable natural snow cover to form and last, will be analysed. This will be done using data on the number of days with snow cover, and the number of days with snow cover deeper than $30 \mathrm{~cm}$ and $50 \mathrm{~cm}$, measured by the meteorological stations at Rateče, Kredarica, Planina pod Golico and Lisca from December to March.

The linear trend of days with snow cover is negative for Rateče and Lisca while the other two meteorological stations do not indicate any change. At Rateče, there were 110 days with snow cover in the four-month period of the first decade on average, 96 days 


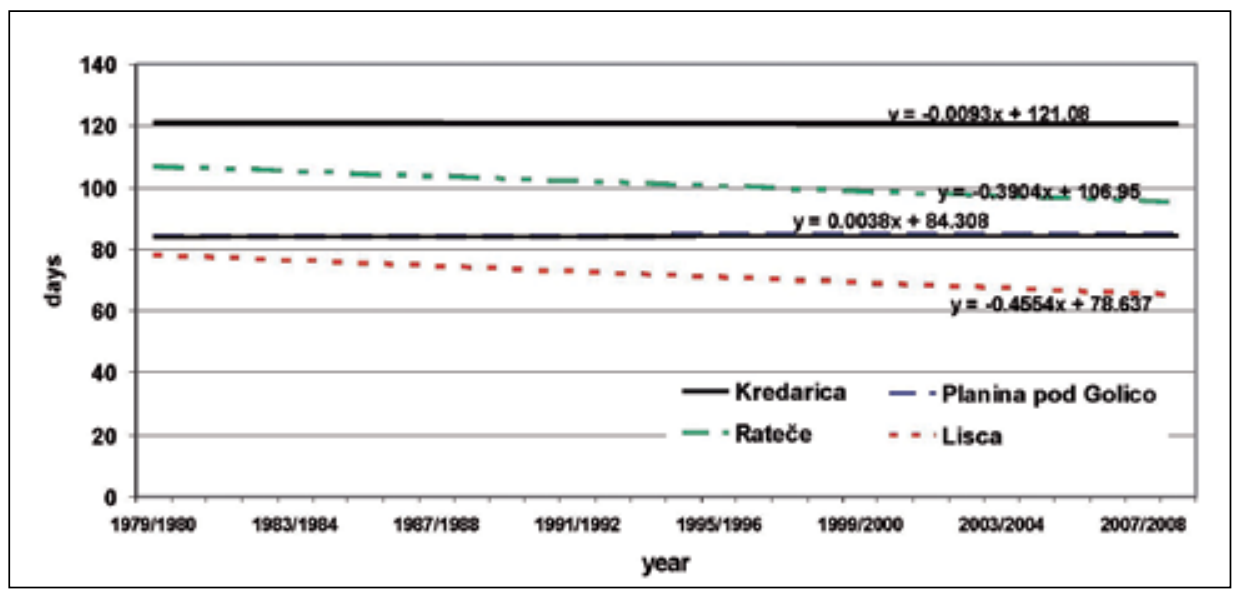

Fig. 6 Linear trend of the number of days with snow cover for the meteorological stations Rateče $(864 \mathrm{~m})$, Kredarica (2514 m), Planina pod Golico (970 m) and Lisca (937 m) in December, January, February and March from 1979/1980 to 2008/2009

Sl. 6. Linearni trendovi broja dana sa snježnim pokrivačem s meteoroloških postaja Rateče (864m), Kredarica (2514 m), Planina pod Golico $(970$ m) i Lisca $(937$ m) u prosincu, siječnju, veljači i ožujku od 1979/80. do 2008/09.

* Data for Lisca was measured over the 1985-2009 reference period

* podaci za Liscu su za razdoblje 1985 - 2009.

in the second decade, and 97 days in the third. The data from the Planina pod Golico meteorological station for the same period is as follows: 93 days, 70 days and 90 days, while Lisca had 65 days with snow cover in the second decade and 69 in the third. It only happened twice in 30 years that snow cover at Kredarica did not last through all the days from December to March.

If we look at the data measured over ten-year periods (without taking data measured at Kredarica into account), we can see that the average number of days with snow cover first decreased (in the decade from 1989/1990 to 1998/1999) and later increased (in the decade from 1999/2000 to 2008/2009). At Rateče and Lisca, the increase was smaller than the decrease, while the measured decrease and increase at Planina pod Golico was almost the same. The strongest linear trend of decrease in the number of days with snow cover was measured at Lisca, which is -14 days in 30 years. But the reference period for Lisca is only 25 years long (1984/1985-2008/2009) and, as such, is not completely comparable to the other stations. Rateče takes second place with -12 days, while the trends of decrease for Planina pod Golico and Kredarica are practically inconsiderable. As was already mentioned, the mere occurrence of snow cover is not enough for good skiing conditions. We defined at least $30 \mathrm{~cm}$ deep snow cover as the main condition that enables skiing.

Fig. 7 clearly indicates that the further development of winter tourism at low elevations (below $1000 \mathrm{~m}$. a.s.1.) is threatened because of the negative trend of days with snow cover. A decreasing trend in the number of days with snow cover deeper than $30 \mathrm{~cm}$ is distinctive for the measurements of all of the meteorological stations, except for Kredarica, where 


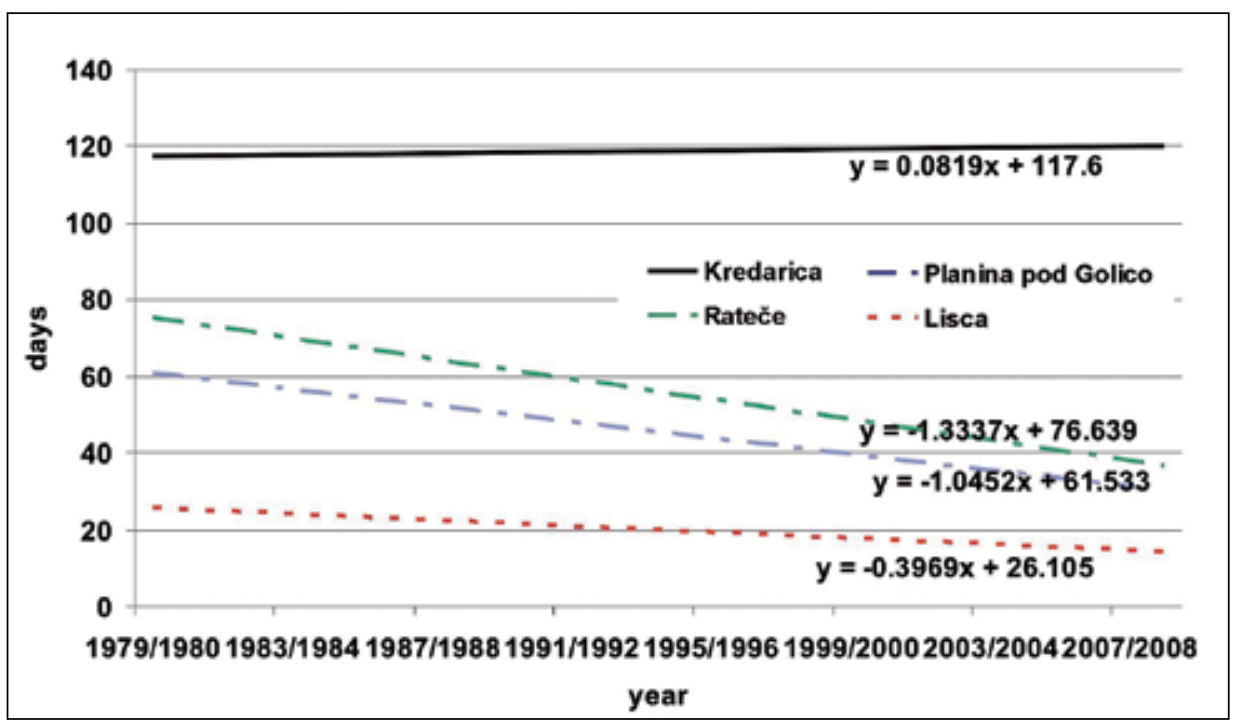

Fig. 7 Linear trend of the number of days with snow cover thicker than $30 \mathrm{~cm}$ from the meteorological stations Rateče (864 m), Kredarica (2514 m), Planina pod Golico (970 m) and Lisca (937 m) in December, January, February and March from 1979/1980 to 2008/2009

Sl. 7. Linearni trendovi broja dana sa snježnim pokrivačem debljim od $30 \mathrm{~cm}$ s meteoroloških stanica Rateče (864m), Kredarica (2514m), Planina pod Golico (970m) i Lisca (937m) u prosincu, siječnju, veljači $i$ ožujku od 1979/80. do 2008/09.

* Data for Lisca was measured over the 1985-2009 reference period

* podaci za Liscu su za razdoblje 1985 - 2009.

the trend is even positive. The data from Rateče show that there were 78 days with snow cover thicker than $30 \mathrm{~cm}$ in the first decade, 41 in the second and 48 in the third. Planina pod Golico had on average 65, 32 and 39 days with snow cover thicker than $30 \mathrm{~cm}$ in the same periods (respectively), while Lisca had on average 14 days in the second decade and 18 days in the third. Kredarica had 116, 121 and 119 days with snow cover above $30 \mathrm{~cm}$. The difference between Kredarica and the rest of the of the stations can be explained by the fact that the snow cover on Kredarica is thicker due to its high elevation, so that the rise in temperatures does not influence the number of days with snow cover thicker than $30 \mathrm{~cm}$ in the December - March period.

The data on the number of days with snow cover thicker than $30 \mathrm{~cm}$ over a ten year period show that the average number at all of the stations (except for Kredarica) first decreased and then slightly increased. With linear trends taken into account, it can be proved that, at the three stations at lower elevations, the linear trend of the number of days with snow cover thicker than $30 \mathrm{~cm}$ is more negative than the trend of the number of days with snow cover.

Linear trends of the number of days with snow cover thicker than $30 \mathrm{~cm}$ are more explicit at all of the stations at low elevations, while the trend at Kredarica is not as explicit and is even positive. The most negative trend is at Rateče, where it adds up to -40 days 


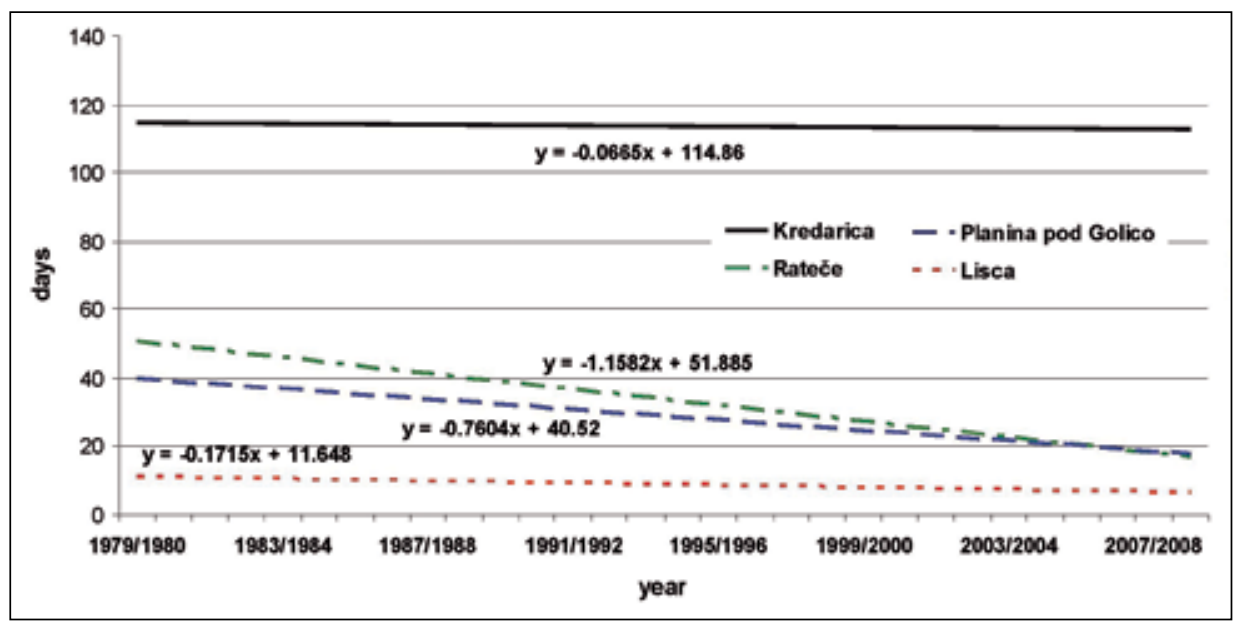

Fig. 8 Linear trend of the number of days with snow cover thicker than $50 \mathrm{~cm}$ from the stations Rateče, Kredarica, Planina pod Golico and Lisca in December, January, February and March from 1979/1980 to 2008/2009

Sl. 8. Linearni trendovi broja dana sa snježnim pokrivačem debljim od $50 \mathrm{~cm}$ s meteoroloških stanica Rateče (864m), Kredarica (2514m), Planina pod Golico $(970 m)$ i Lisca $(937 m)$ u prosincu, siječnju, veljači $i$ ožujku od 1979/80. do 2008/09.

* Data for Lisca was measured over the 1985-2009 reference period

* podaci za Liscu su za razdoblje 1985 - 2009.

per 30 years, and it is strong at Planina pod Golico as well, where it reaches -31 days. At Lisca, with a 25 -year long reference period, the trend is lower with -12 days, while it reaches 2 days at Kredarica.

The indicator of the number of days with snow cover thicker than $50 \mathrm{~cm}$ provides information on when and how long natural snow cover provides very good skiing conditions. Here the trends over a 30-year period are the strongest.

In the first decade, there were 56 days with at least $50 \mathrm{~cm}$ deep snow cover at Rateče, in the second only 17 and in the third 29. Planina pod Golico had 46, 13 and 27 days (respectively) in the same periods, while Lisca (only two whole ten-year reference periods) had 4 in the second and 9 days in the third. The decreases in the first and the second decade are very marked; the increase in the last decade is also significant, but at Rateče and Planina pod Golico it still reaches only half of the value from the first decade.

In high Alpine areas, at Kredarica, the trend is completely different. In the first decade, there were, on average, only 111 days with snow cover thicker than $50 \mathrm{~cm}$ due to a green winter in 1988/89, when there were only 35 days with more than $50 \mathrm{~cm}$ of snow. In the second decade, there were 119 days, and 112 days in the third. Linear trends confirm the values for a single decade. The trend at Rateče amounts to -35 days per 30 years, at Planina pod Golico -23 days and at Lisca, where the period is only 25 years long, -5 days with -2 days at Kredarica. 
How can we predict the future development of Slovenian ski tourism with the help of linear trends?

The most realistic estimation of the further development of winter tourism in Slovenia can be made with the so-called 100-day rule. "Reliable natural snow can be defined when there are at least seven winters in a decade with snow cover appropriate for skiing, lasting for at least 100 days. Usually at least $30 \mathrm{~cm}$ of snow is needed for good skiing, while in higher Alpine areas, where the terrain is more rocky, it takes $1 \mathrm{~m}$ or even more. Winter tourism in Slovenia is based on smaller ski resorts and the 100-day rule applies only for the bigger ones, while for the smaller ones 60 skiing days are enough" (Vrtačnik Garbas, 2008 A). If we consider the 100-day rule, we discover that Slovenia has very unfavourable conditions in terms of snow, and judging by the results of the research, the conditions will only get worse over time.

If we look at the Figs. 7 and 8 we can notice that the trends in snow cover thicker than 30 and $50 \mathrm{~cm}$ at Rateče and Planina pod Golico are very similar; the decreasing trend can be noticed at Lisca as well, but it is slightly different. The only exception is Kredarica, where the number of days with snow cover remains the same, despite the rise in temperatures. This is connected with the fact that the snow cover at Kredarica is very thick and, as such, not as affected by the rise in temperatures; the snow does not thaw considerably in the periods between December and March. Usually, the snow cover at Kredarica begins to thaw and thin out at the end of April or the beginning of May, while it begins to form in October or November at the latest.

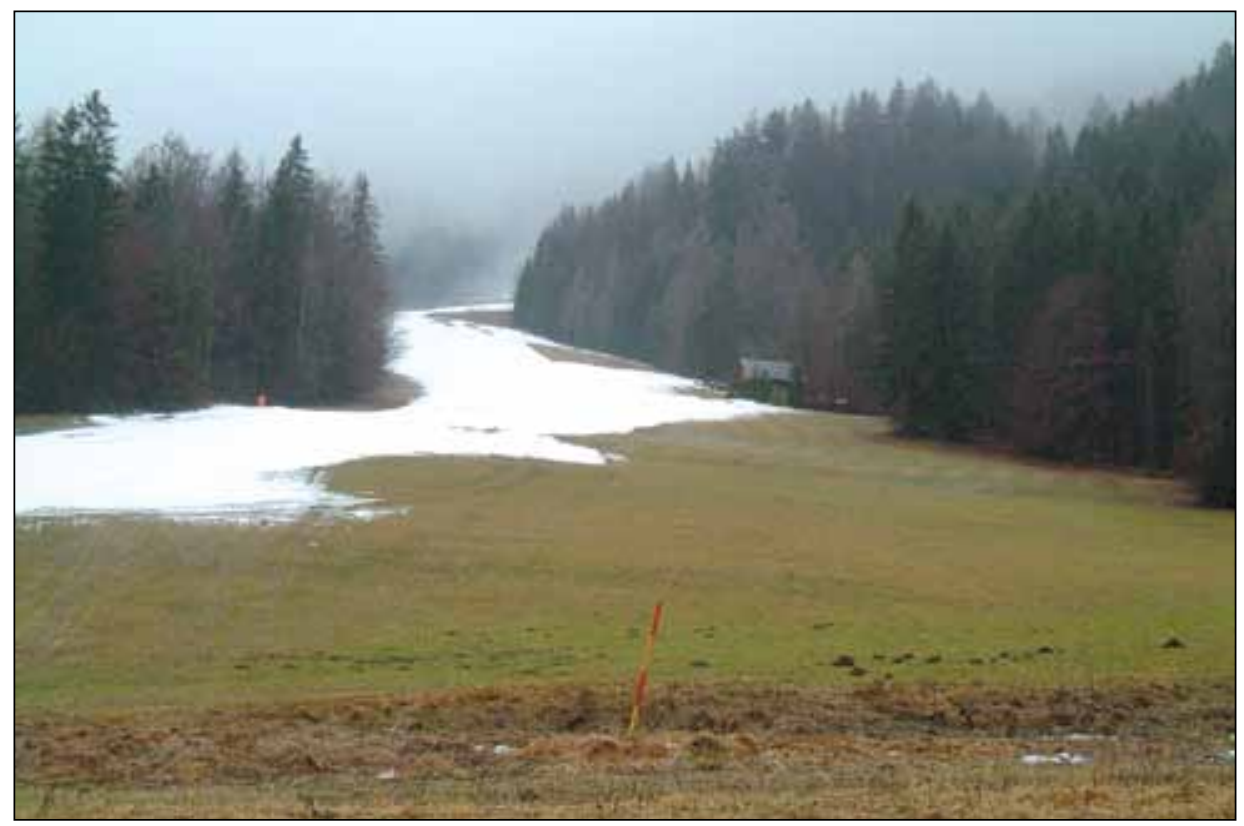

Fig. 9 Skiing at low elevations, such as Kranjska Gora is increasingly unpredictable

Sl. 9. Skijanje na nižim nadmorskim visinama, poput Kranjske Gore, je sve više nepredvidljivo. 
Another characteristic of Slovenia's winter climate needs to be mentioned: the great variability of the weather or, in this case, of snow cover. The variability coefficient of snow cover deeper than $50 \mathrm{~cm}$ is 108 at Rateče, 125 at Lisca, 118 at Planina pod Golico and only 16 at Kredarica, this being very informative regarding the variability of the snow cover. There can be great amounts of snow, which last long, or there can be no snow at all. It is predicted that this variation will become even greater in the period of climate change. This means that white winters or at least periods with snow cover that is thick enough will still occur, but the reliability of snow cover, which is definitely an important factor for developing quality ski tourism, cannot be assured. Data shows that the reliability will weaken even further.

\section{FINDINGS AND CONCLUSIONS}

The research has shown that there are many obvious changes in the depth of snow cover and temperatures in the months most appropriate for skiing, and that they confirm the predictions of global warming and the conditions for winter tourism in Slovenia becoming worse. Linear temperature trends are very similar and indicate that temperatures have increased from 1.3 to $1.4{ }^{\circ} \mathrm{C}$ per 30 years at the elevations around $900 \mathrm{~m}$. At Kredarica, which lies in high alpine areas $(2514 \mathrm{~m})$ the trend is at $1^{\circ} \mathrm{C}$.

The average temperature rose by $0.7^{\circ} \mathrm{C}$ in the $1980-2009$ period in comparison to the 1961-1990 period at Rateče as well as at Kredarica. Especially at Rateče and Planina pod Golico, the decreasing trend of days with snow cover above 30 and above $50 \mathrm{~cm}$ from December to the end of March is very strong. For a $30 \mathrm{~cm}$ deep snow cover, it amounts to 40 or 31 fewer days and for a snow cover $50 \mathrm{~cm}$ deep to 23 or 35 fewer days.

With rising temperatures it is very likely that the number of days with snow cover will decrease even more in the future. Nevertheless, this does not mean that every consecutive winter will be less winter-like. It is also possible that short periods of relatively colder and more snowy winters will appear. We must not forget that Slovenia lies in the moderate climate zone at the junction of the Alps, the Mediterranean, the Dinaric Alps and the Pannonian lowland (Ogrin D., Plut, 2009, p. 73-95), which can cause great variability in weather. On the other hand, the global and regional climate also depends on several other factors, such as solar activity, prevailing tracks of Mediterranean cyclones, and the like.

All of this constitutes a highly variable climate and, consequently, variable snow conditions. The climate change era in which we are living today is increasing this variability even more. Slovenian ski resorts are even more vulnerable in comparison to other ski resorts in the Alps, since they lie at lower elevations. Only one of them lies above $2000 \mathrm{~m}$ and only two above $1600 \mathrm{~m}$. In the long run, this means that winter tourism will need to focus on other activities, such as spa tourism (water parks, swimming pools, relaxation centres); they will also need to focus on the summer season and on transitional periods as well.

Some of the ski centres have already adopted this strategy and are developing tourist services throughout the year (Kranjska Gora, Rogla), and others are not (Vogel). However, there is no alternative, since the predictions say that the warming trend will continue. Ski resorts, especially ski centres, which focus only on skiing and have no summer season (such as Stari vrh, Cerkno) can expect to have more difficulties with ensuring adequate 
economical conditions until skiing becomes unprofitable. In the following decades, all Slovenian ski centres except Kanin will have to shift their offer more and more to an allyear season.

\section{SUMMARY}

Climate changes affect winter tourism significantly. Higher temperatures cause less snowfall and more rain, and snow cover forms later and melts earlier. This means a shorter skiing season, higher investment for artificial snow production, higher energy consumption and increased pressure on local water resources when providing enough water for artificial snow production (Hahn, 2004). The article shows us climate trends in the Slovenian Alpine region, especially in the months of the ski season, which means the period from December to March. The study focused on snow cover indicators such as days with snow cover, days with snow cover thicker than $30 \mathrm{~cm}$ and days with snow cover thicker than $50 \mathrm{~cm}$, and on temperature indicators such as average temperature in the months from December to March and average annual temperature. Four meteorological stations from the Slovenian Alpine and pre-Alpine regions were taken into consideration in this research: Kredarica (2514 m a.s.1.), Rateče (864 m a.s.1.), Planina pod Golico (970 m a.s.1.) and Lisca (937 m a.s.1.). The problem when calculating climate trends occurred due to incomplete data sets on several other meteorological stations, such as Krvavec, Vojsko, Vogel, with even the Lisca station having only 25 years of continuous data. However, since Lisca lies in the eastern part of Slovenia and is the only station from the eastern Slovenian pre-Alps, we took it into research with the remark that the set is only 25 years long. The period of research for the other stations was from winter 1979/1980 - to winter 2008/2009. Temperature trends from the Slovenian Alps confirmed predictions that the climate is warming. The mean annual temperature in the 30-year period from 1980 - 2009 on Kredarica and at Rateče was $0.7{ }^{\circ} \mathrm{C}$ higher than in the $1961-1990$ period, which should be a matter of concern. The linear warming trend was the strongest at Rateče and Planina pod Golico with $1.4^{\circ} \mathrm{C}$ per 30 years, while the trend was only slightly weaker by a tenth at Lisca. The warming trend is weaker at Kredarica with $1{ }^{\circ} \mathrm{C}$, which indicates climate conditions on elevations around $2500 \mathrm{~m}$, where only one Slovenian ski area lies.

Snow conditions have changed significantly, especially at lower elevations. The number of days with snow cover fell evidently only at Lisca (-14 days) and Rateče (-12 days), while the linear trends were neutral at Planina pod Golico and Kredarica. However, the number of days with snow cover thicker than 30 and $50 \mathrm{~cm}$ showed a decrease at all three stations at lower elevations, while the results showed a neutral trend at Kredarica. The most negative trend for days with snow cover over $30 \mathrm{~cm}$ is at Rateče, where it is -40 days per 30 years, and -31 days at Planina pod Golico, whereas Lisca, with its 25-year long reference, shows a lower trend with -12 days. The number of days with snow cover thicker than $50 \mathrm{~cm}$ is an indicator, which provides us information on when and for how long natural snow cover provides very good skiing conditions. Again, Kredarica shows a neutral trend, because in the December - March period at this elevation, in spite of warming, temperatures are still too low and snow cover exceeds $50 \mathrm{~cm}$ usually much before December, and is usually thicker than $50 \mathrm{~cm}$ even at the start of June. However, trends again showed rapid decrease at other stations: - 35 days at Rateče, -23 at Planina pod 
Golico and -5 days at Lisca, where the number of days with snow cover thicker than 50 $\mathrm{cm}$ was small even 25 years ago. When dealing with natural conditions for ski tourism in Slovenia one must also consider the greater variability in the weather and snow conditions.

\section{REFERENCES}

Abegg, 1996. Klimaänderung und Tourismus. Klimafoschung am Beispiel des Wintertourismus in der Schweizer Alpen. Cv: Vrtačnik Garbas K., 2008. Posledice klimatske spremenljivosti v središčih zimsko športne rekreacije v Sloveniji. Doktorska disertacija. Litija. 480 str.

Archive of The Environmental Agency of the Republic of Slovenia;

Barry, R., G., Armstrong, R., Callaghan, T., Cherry, J., Gearheard, S., Nolin, A., Russel, D., Zöckler, C. 2007 : Global overview for ice \& snow. Snow. United Nations Environmental Programme, 238 p.

Dolinar M., Nadbath M., Vičar Z., Vertačnik G., Pavčič B., 2010. Spremljanje podnebja v Sloveniji. In: Okolje se spreminja, podnebna spremenljivost Slovenije in njen vpliv na vodno okolje. MOP RS ARSO. Ljubljana. p.16-36.

Dolinar, M., Vertačnik, G., 2010: Spremenljivost temperaturnih in padavinskih razmer v Sloveniji. In: Okolje se spreminja. Agencija Republike Slovenije za okolje. Ljubljana, p. 37 - 40.

Hahn, F., 2004: Umetno zasneževanje na območju Alp, Osnovni dokument. Alpmedia informacijska služba za Alpe. 18 str. www. http://www cipra.org/sl/alpmedia/dosjeji/11 (4. 2. 2009)

König, U., 1998: Tourism in a warmer world : Implications of climate change due to enhanced greenhouse effect to the ski industry in the Australian Alps. Zürich, Philosophiche Fakultät II der Universität Zürich, 229 p.

Kohler, T., Maselli, D., 2009: Mountains and Climate Change. Centre for Development and Environment (CDE), Institute of Geography, University of Bern. Bern, 80 p.

Ogrin D., 2003. Spreminjanje temperature zraka in padavin po letnih časih v Ljubljani in Trstu v obdobju 18512002. Dela 20, Oddelek za geografijo FF UL, Ljubljana, p. 115- 131.

Ogrin, D., 2008. Räumliche Vielfalt von Klima und Vegetation. In: Slowenien, Transformationen und kleinräumige Vielfalt (ed. Albrecht V., Drozg V.), Natur-Raum-Gesellschaft 5, Institut für Humangeographie, Frankfurt am Main, p. 76-93.

Ogrin, D., Plut, D., 2009: Aplikativna fizična geografija Slovenije. Ljubljana. Znanstvena založbe Filozofske fakultete Univerze v Ljubljani, 246 p.

Perko, D., Orožen Adamič, 1998: Slovenija - pokrajine in ljudje. Ljubljana. Mladinska knjiga, 735 p.

Vrtačnik Garbas, K., 2008 A: Bomo v prihodnosti namesto v smuki uživali v nabiranju regrata? Gea, 18, January 2008. p. 8-11.

Vrtačnik Garbas K., 2008: Posledice klimatske spremenljivosti v središčih zimsko športne rekreacije v Sloveniji. Doktorska disertacija. Litija. 480 str.

Received (Primljeno): $2010-12-31$

Accepted (Prihvaćeno): $2011-04-25$

\author{
Matej Ogrin, \\ Department of Geography \\ Faculty of Arts \\ University of Ljubljana \\ SI-1000 Ljubljana, Aškerčeva 2 \\ matej.ogrin@siol.net
}

